\title{
PELIBATAN ORANG TUA BERNUANSA KEARIFAN LOKAL DALAM PEMBELAJARAN ANAK USIA DINI
}

\author{
WAHYUNIATI ${ }^{1}$ - HUSNI ABDILLAH ${ }^{2}$ \\ Fakultas Tarbiyah dan Keguruan Universitas Islam Negeri Sunan Ampel \\ Surabaya. JL. A. Yani 117, Surabaya Jawa Timur 60237 \\ Email: husniabdillah@uinsby.ac.id
}

\begin{abstract}
This study aims to: Analyzing the form of parent participation in school learning activities that have a value of local knowledge, Subjek research include school principals, teachers and parents from TK Falasifa, TK Baiturrahman and RA jannatul Abror. This research use descriptive qualitative method, Data collection techniques such as interviews and in-depth observation. While analysis of the data used include: coding step, reduction, display and conclusion. The results of the research, that: The activities developed nuanced local wisdom to develop parent involvement consists of: Tahlil and istighosah routine on Friday earlier month involving parents, Rated affection by sharing with the orphans of tuition. Values of mutual cooperation and "ngalapberkah", Visits to the Old Orphanage Together, value mutual cooperation, the value Sepiingpamrihrameinggawe, and tepaselira value.Paguyupan value, and the perception of a teacher is considered as a highly mbarokahi, Ikhlas kiaine ilmunevalue, patuhgurunebarokahuripe value. Guardians of students willing to contribute and work together.
\end{abstract}

Keywords: Teacher, involvement of parents, local wisdom

Abstrak: Penelitian ini bertujuan untuk menganalisis bentuk partisipasi orang tua dalam kegiatan pembelajaran di sekolah yang memiliki nilai kearifan lokal. Subjek penelitian meliputi kepala sekolah, guru maupun orang tua dari TK Falasifa surabaya, TK Baiturrahma Sidoarjo dan RA Jannatul Abror Tuban. Metode yang dipakai adalah deskriptif kualitatif dengan teknik pengumpulan data berupa wawancara dan observasi mendalam. Sedangkan analisa data yang digunakan meliputi: langkah koding, reduksi, display dan penarikan kesimpulan. Hasil penelitian, bahwa: Kegiatan yang bernuansa kearifan lokal yang dikembangkan untuk mengembangkan keterlibatan orang tua terdiri dari: Tahlil dan istighosah rutin pada hari jum'at awal bulan yang melibatkan orang tua, Nilai Kasih Sayang melalui berbagi dengan anak yatim dari uang iuran. nilai gotong royong dan ngalap berkah, Kunjungan Ke Panti Asuhan Bersama orang Tua, Nilai gotong royong, nilai sepi ing pamrih rame ing gawe, nilai tepa selira. Adanya Paguyuban wali murid Dan adanya anggapan sosok guru dianggap sebagai sosok yang mbarokahi, Ikhlas kiaine manfaat ilmune, patuh gurune barokah uripe. Wali santri rela memberi sumbangsih dan bergotong royong.

Kata kunci: Guru, keterlibatan orang tua, kearifan lokal

Kultur pendidikan di dalam proses pendidikan. Kultur ini Indonesia menempatkan negara dan menempatkan sekolah sebagai sekolah sebagai institusi sentral institusi terdepan yang harus 
berupaya keras dengan segala keluarga merupakan bagian dari jalur sumber daya yang dimilikinya untuk menempa peserta didik sesuai dengan tujuan yang termaktub dalam rambu-rambu pendidikan. Sementara institusi negara diposisikan sebagai lembaga regulator yang bertugas untuk menyiapkan kurikulum, meyelenggarakan proses evaluasi nasional, penyiapan dan peningkatan kapasitas guru hingga pendanaan operasional pendidikan.

Dominasi dua institusi ini meninggalkan ruang yang seharusnya diisi oleh institusi keluarga, yaitu orangtua. Hamalik (1990:15) mengatakan bahwa orang tua memiliki tugas dan tanggung jawab terhadap perkembangan belajar anak-anaknya. Orangtua diharapkan memenuhi kebutuhan belajar anak secara psikis, seperti memuji, menegur, memberi hadiah, mengawasi, turut serta pada program kegiatan sekolah anak, dan lain-lain.

Menelisik pada UndangUndang Nomor 20 Tahun 2003 tentang sistem pendidikan nasional, disebutkan bahwa pendidikan pendidikan luar sekolah yang diselenggarakan dalam keluarga dan yang memberikan keyakinan agama, nilai budaya, nilai moral dan keterampilan. Undang-undang ini memperkuat posisi dan peran keluarga yang memiliki tanggung jawab yang sama dalam pendidikan anak. Pengetahuan agama, moral, budaya hingga ketrampilan merupakan ranah yang harus diberikan kepada anak.

Seymour

(Ife, 2002)

mengidentifikasi beberapa sikap yang mengindikasikan minimnya keterlibatan orang tua seperti berlaku pasif dalam proses pendidikan anak, bersifat apatis dengan beragam alasan, merasa puas dengan model pendidikan yang bersifat khusus, dankomunikasi yang jelekantara orang tua dengan sekolah.

Minimnya partisipasi merupakan fakta yang menggelisahkan. Hal ini dikarenakan keterlibatan orangtua memiliki dampak positif terhadap perkembangan belajar anak. 
Dampak positif keterlibatan orang tua dalam pendidikan anak dapat terlihat apabila guru dan orang tua dapat memahami bentuk, tujuan, dan makna dari keterlibatan orang tua itu yang salah satunya menurut Jeynes makna dari keterlibatan orang tua adalah partisipasi orang tuadalam proses dan pengalaman belajar anak (Hornby, 2011). Itulah sebabnya sekolah yang baik adalah sekolah yang memberikan tempat bagi orang tua untuk ikut terlibat dalam pendidikan anak-anak mereka. Bagaimana orang tua anak melibatkan diri adalah faktor kunci dalam meningkatkan prestasi anak dan juga menjaga kedewasaan mentalnya.

Kearifan lokal sebagai salah satu bentuk sistem pengetahuan yang berkembang di masyarakat dapat digunakan sebagai strategi yang dapat memicu keterlibatan orangtua dalam pembelajaran. Hal tersebut sejalan dengan pendapat Spagnola and Fiese (2007) yang menyatakan bahwa ritual keluarga bisa menjadi jembatan penting dalam membangun iklim yang harmonis dalam sebuah keluarga dan sekolah. Pelibatan orang tua dalam kegiatan sekolah yang memiliki nilai lokal dapat menjadi penjembatan bagi orang tua dan anak usia dini dalam pendidikan mereka terutama dalam pendidikan nilai dan karakter dimana anak masih baru memulai pembentukan karakter melalui pengembangan sikap moral, agama, sosial dan emosional (Mansur 2005).

Guru sebagai entitas penting dalam sekolah dapat melibatkan wali murid dengan memanfaatkan nilainilai kearifan lokal yang berkembang di masyarakat karena Sekolah dianggap sebagai bagian dari masyarakat tidak akan dapat lepas dan melepaskan diri dari nilai, kepercayaan maupun kebiasaan kebiasaan yang berlaku pada masyarakat yang sudah sejak lama dipraktekkan oleh masyarakat sekitar sekolah. Dengan mengakomodir nilai kearifan lokal pada kegiatan sekolah, orang tua akan merasa lebih familiar dan lebih dekat untuk dapat terlibat dalam kegiatan sekolah. 
Berdasarkan latar belakang yang sudah dibuat, dibuat rumusan masalah sebagai berikut: Bagaimana kegiatan yang memiliki nilai kearifan lokal yang mampu mengembangkan keterlibatan orang tua dalam proses pendidikan?. Berdasarkan rumusan tersebut maka maka penelitian ini akan Menganalisis bentuk partisipasi orang tua dalam kegiatan pembelajaran di sekolah yang memiliki nilai kearifan lokal.

\section{METODE PENELITIAN}

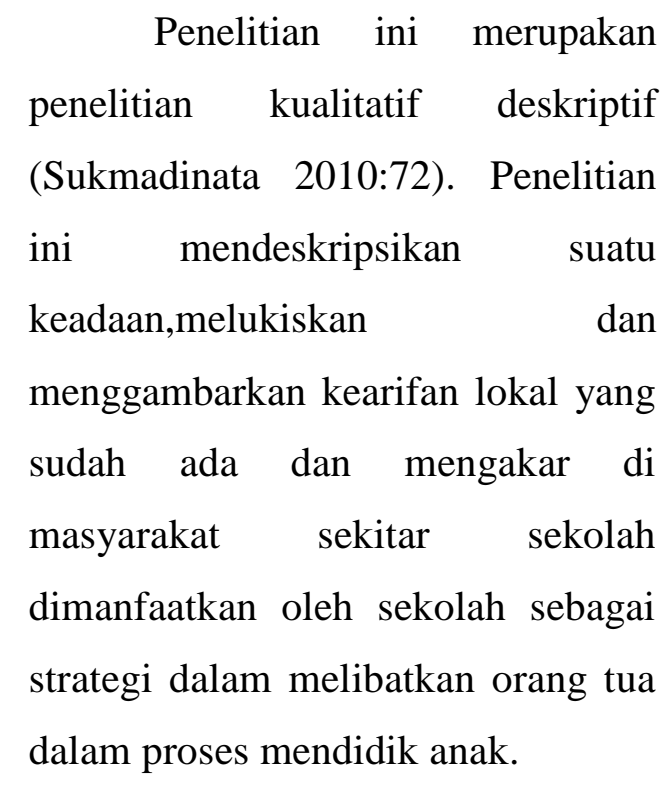

Subyek penelitian ini adalah: kepala sekolah, guru dan orang tua murid di TK Falasifa Surabaya,TK Baiturrahman Seruni, dan RA jannatul Abror Jl hamim Yasin Desa
Plandirejo Plumpang Tuban.

Pemilihan orang tua menggunakan teknik purposive sampling berdasarkan intesitas relasi orang tua dengan sekolah atau yang memahami konsep pembelajaran parenting education.

Teknik Pengumpul data yang digunakan adalah wawancara, observasi dan dokumentasi. Wawancaradilakukankepada guru, orang tua siswa dan siswa, wawancara bersifat terbuka dan fleksibel. Adapun observasi non partisipan dilakukan dengan cara mencatat, menganalisis, dan membuat kesimpulan tentang data yang diperlukan dalam penelitian. Sedangkan dokumentasi, diperoleh dari dokumen rencana kerja sekolah, program sekolah, kurikulum sekolah, silabus, dan rencana pelaksanaan pembelajaran, dan papan slogan . Peneliti juga mengambil dokumentasi berupa foto dan papan slogan di lingkungan sekolah.

Teknik analisis data dalam penelitian ini terdiri koding, dari reduksi data, penyajian data, dan 
diakhiri dengan penarikan kesimpulan. Pada tahap reduksi, Peneliti memilah-milah data dari kepala sekolah, guru, orang tua maupun siswa yang diperoleh karena merupakan data yang masih kompleks. Kemudian pada tahap penyajian data ini, peneliti menyajikannya dalam bentuk tabel yang berisi deskripsi singkat dari data yuang sudah dipilah berdasarkan sumber informan dan lokasi subyek penelitian. Setelah itu data yang ada diinterpretasikan kemudian dianalisis untuk memperoleh kesimpulan pada tahap penarikan kesimpulan .

Dalam pengujian kredibilitas penelitian ini, peneliti menggunakan triangulasi. Triangulasi dalam pengujian kredibilitas ini diartikan sebagai pengecekan data dari berbagai sumber dengan berbagai cara, dan berbagai waktu (Djam'an
Satori dan Aan Komariah, 2011: 170). Dalam menguji kredibilitas data, peneliti menggunakan triangulasi dan bahan referensi, Triangulasi yang digunakan peneliti adalah triangulasi teknik dan sumber.

\section{HASIL PENELITIAN DAN PEMBAHASAN}

1. Bentuk kegiatan yang mengembangkan keterlibatan Orang Tua dalam Pendidikan anak di Sekolah dan di Rumah.

Berdasarkan data yang diperoleh di tiga sekolah tempat penelitian, maka dapat ditemukan beberapa kegiatan yang dianggap dapat mengembangkan keterlibatan orang tua dalam pendidikan anak baik di rumah maupun di sekolah yang disajikan dalam tabel sebagai berikut:

\section{Tabel 1}

Bentuk Kegiatan Yang Mengembangkan Keterlibatan Orang Tua

\begin{tabular}{|c|c|}
\hline Nama TK & $\begin{array}{c}\text { Bentuk kegiatan } \\
\text { yang mengembangkan keterlibatan orang tua }\end{array}$ \\
\hline TK F & $\begin{array}{l}\text { Tahlil dan istighosah rutin yang melibatkan orang tua, Kegiatan } \\
\text { Outbond, Rekreasi/Karya wisata, Peringatan, Hari kartini, } \\
\text { Parenting, Orang tua menyimak hafalan anak pada materi tertentu. }\end{array}$ \\
\hline TK S & Buku Monitoring penghubung orang tua-guru, Orang Tua \\
\hline
\end{tabular}




\begin{tabular}{ll}
\hline & membantu menghafal gerakan shalat anak, Orang tua membantu \\
& menghafal lafadz Do'a, Kunjungan Ke Panti Asuhan Bersama \\
& orang Tua, Home visit ke rumah wali murid \\
\hline RA J & Parenting, Orang Tua Membantu Anak melaksanaklan \\
& simulasi Shalat yang benar, Peringatan Hari besar islam \\
& (contoh maulid dan isul adha), Tahlil dan istighosah rutin \\
& satu bulan sekali, Buku Monitoring Penghubung, Ada \\
& Paguyuban wali murid \\
\hline
\end{tabular}

2. Bentuk kegiatan bernuansa kearifan lokal yang mengembangkan keterlibatan

Orang Tua dalam Pendidikan anak di Sekolah dan di Rumah

Dari variasi kegiatankegiatan yang dilalukan oleh tiga sekolah yang menjadi tempat penelitian, terdapat kegiatan yang mengandung muatan nilai kearifan lokal. Adapun kegiatan dan penjelasannya dapat dijelaskan dalam tabel sebagai berikut:

Tabel 2

Bentuk Kegiatan Bermuatan Kearifan Lokal

\begin{tabular}{|c|c|c|c|}
\hline Nama TK & & $\begin{array}{c}\text { Bentuk kegiatan dan muatan } \\
\text { Kearifan Lokal }\end{array}$ & $\begin{array}{c}\text { Kesimpulan Kegiatan } \\
\text { Bermuatan Kearifan lokal }\end{array}$ \\
\hline TK F & $\vec{\nu}$ & $\begin{array}{l}\text { Tahlil dan istighosah rutin, } \\
\text { Nilai gotong royong } \\
\text { ngalap berkah. }\end{array}$ & $\begin{array}{l}\text { Kegiatan Keagamaan (Tahlil, } \\
\text { istighosah, maulid, isra' } \\
\text { mi'raj) }\end{array}$ \\
\hline TK S & $>$ & $\begin{array}{l}\text { Sambatan kerja bakti (Gotong } \\
\text { royong membangun sekolah; } \\
\text { Menabung dan mencicil uang biaya } \\
\text { sekolah) } \\
\text { Home visit ke rumah wali murid, } \\
\text { (Nilai gotong royong, nilai sepi ing } \\
\text { pamrih rame ing gawe, nilai tepa } \\
\text { selira) }\end{array}$ & $\begin{array}{l}\text { Gotong Royong (Sambatan, } \\
\text { Kerja Bakti, Sepi ing pamrih, } \\
\text { rame ing gawe, tepa selira) } \\
>\quad \text { Paguyuban wali murid } \\
>\text { Ngalap Berkah (Ikhlas kiaine } \\
\text { manfaat ilmune, patuh } \\
\text { gurune barokah uripe). }\end{array}$ \\
\hline RA J & $>$ & $\begin{array}{l}\text { Peringatan Hari besar islam } \\
\text { (contoh maulid dan isra' } \\
\text { mi'raj), Tahlil dan istighosah } \\
\text { rutin satu bulan sekali, } \\
\text { Adanya Paguyuban wali } \\
\text { murid } \\
\text { Guru sosok yang mbarokahi } \\
\text { Semangat (Ikhlas kiaine }\end{array}$ & \\
\hline
\end{tabular}




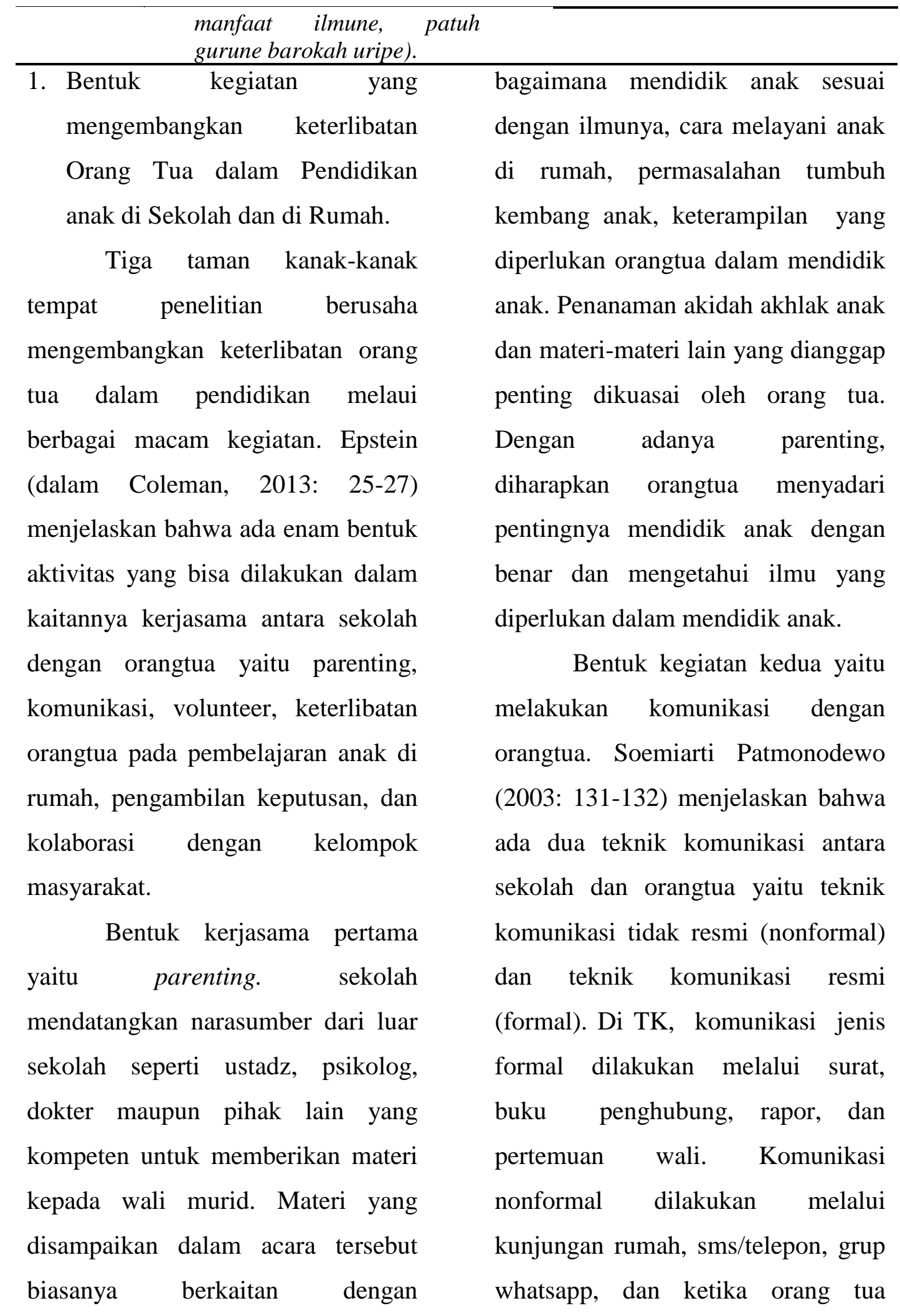


menjemput atau mengantarkannya. Komunikasi sangat penting dilakukan karena bermanfaat dalam menerapkan pendidikan yang berkesinambungan. Pihak sekolah dan orangtua berpandangan jika hanya salah satu pihak saja yang memberikan pendidikan, maka hasilnya juga tidak akan optimal karena pembelajaran dilakukan maksimal hanya selama satu jam. Hal ini senada dengan pendapat Slamet Suyanto (2005: 226) yang menjelaskan bahwa waktu yang dihabiskan anak di TK jauh lebih sedikit dibanding waktu anak di rumah. Oleh karena itu apa yang dipelajari di sekolah hendaknya diteruskan di rumah sehingga hasilnya lebih baik.

Dalam konteks tiga TK tempat penelitian, buku penghubung merupakan sarana komunikasi yang sangat bermanfaat karena dengan adanya buku penghubung, orang tua akan tahu apa yang harus dilakukan terhadap anak ketika di sekolah, misalnya menemani anaknya untuk belajar menghafal doa doa, gerakan shalat dan kegiatan lainnya. Dengn buku penghubung orang tua juga mengetahui kegiatan guru dalam pembelajaran dan perkembangan apa yang dialami anaknya ketika di sekolah, orag tua juga secara tidak langsung memiliki tanggung jawab untuk melihat perkembangan anak setiap hari.

\section{Bentuk kerjasama ketiga} yaitu volunteer. Kegiatan volunteer ini banyak dilakukan di tiga sekolah tempat penelitian. Misalnya ketika peringatan hari besar islam seperti idul adha, orang tua siswa ada yang membantu memasak hewan qurban dan sebagainya, Orang tua membantu sekolah ketika di kelas sebagai pengajar maupun ketika di luar kelas dalam berbagai kegiatan seperti menjadi panitia acara peringatan kartini, menghias kereta karnaval, merias anak, mengantar anak latihan untuk persiapan lomba drumben, menjadi pengurus orangtua, dan menjadi panitia acara sekolah. Orang tua juga ada yang bersedia menyumbangkan tenaga untuk membangun atau 
merenovasi sekolah, dapat dikatakan andil orang tua sangat besar dalam sumbangsih kemajuan sekolah.

$\begin{array}{rlr} & \text { Dengan } & \text { adanya bantuan } \\ \text { tenaga dari } & \text { orangtua, guru }\end{array}$
mengungkapkan bahwa tugas mereka menjadi lebih ringan ketika sekolah mengadakan kegiatan dan proses pembangunan sekolah berjalan lancar sesuai dengan rencana. Hal tersebut selaras dengan teori Coleman (2013:79) yang menyatakan bahwa pekerjaan guru akan menjadi lebih mudah ketika ada keterlibatan dari orangtua untuk mendukung pembelajaran kelas, program, dan kegiatan yang ada di sekolah.

Bentuk kerjasama keempat yaitu orangtua berperan sebagai guru dengan mengajarkan dan membantu anak untuk mengejar ketinggalan pembelajaran di kelas ketika di rumah. Selain itu, orangtua juga melanjutkan pembelajaran anak di rumah, mendampingi anak belajar, mengulang materi sekolah, dan menerapkan apa yang dibiasakan di sekolah melalui buku penghubung sehingga bisa menjadi contoh bagi anak. Hal ini sesuai dengan teori menurut Slamet Suyanto (2005:226) yang menyatakan bahwa buku penghubung digunakan untuk memberi tahu orangtua apa yang sedang dipelajari anak di sekolah.

2. Bentuk Kegiatan Bernuansa kearifan Lokal untuk Mengembangkan keterlibatan Orang Tua dalam Pendidikan Anak

Berdasarkan data yang diperoleh, terdapat beberapa kegiatan, nilai, keyakinan yang bernuansa kearifan lokal dan digunakan oleh guru di tiga sekolah TK/RA untuk mengembangkan keterlibatan orang tua dalam kegiatan proses pembelajaran, maupun kegiatan sekolah yang lain. Kegiatan tersebut secara global dibagi dalam empat bentuk yaitu: (a) Kegiatan Keagamaan (Tahlil, istighosah, maulid, isra' mi'raj); (b). Gotong Royong (Sambatan, Kerja Bakti, Sepi ing pamrih, rame ing gawe, tepa selira) (c). Paguyuban wali murid; dan (d). Ngalap Berkah (Ikhlas 
kiaine manfaat ilmune, patuh gurune barokah uripe). Secara singkat akan dibahas keempat hal sebagai berikut.

a. Kegiatan Keagamaan (Tahlil, istighosah, maulid, isra' mi'raj)

Data penelitian ini diambil di tiga sekolah dan tiga kota yang berbeda. TK Falasifa terletak disurabaya, TK Baiturrahma di Sidoarjo dan RA Jannatul Abror terletak Tuban. Melihat dari wilayah geografisnya, tuban, surabaya dan sidoarjo masuk dalam wilayah pesisir utara jawa timur. Berdasarkan sejarahnya, pada awalnya daerah pesisir utara jawa timur lebih banyak diwarnai oleh budaya Kerajaan Hindu Mataram. Kemudian seiring dengan masuk dan berkembangannya agama islam diawali pada abad VII masehi maka kebudayaan islam lebih banyak mempengaruhi terbentuknya karakter masyarakat santri meskipun kebudayaan mataraman tidak senantiasa hilang karena terjadi akulturasi budaya islam dengan budaya lokal pada saat itu sehingga wilayah barat-selatan Jawa Timur dikatakan berciri "abangan" sedangkan wilayah pantai utara Jawa Timur berciri Santri.

Dengan keadaan masyarakat yang memiliki karakter budaya jawa timur pesisir bercampur dengan budaya islam menghasilkan kearifan lokal yang memiliki campuran budaya keduanya selaras dengan hasil pemikiran Muqoyyidin sebagai berikut:

"...Tidak dapat dipungkiri
bahwa Islam di Jawa
memang datang di wilayah
pesisir pada zaman itu.
Nama-nama pelabuhan,
seperti Tuban, Gresik dan
Surabaya sudah tidak asing
lagi. Pelabuhan-pelabuhan
ini menjadi daerah transit
bagi kaum pedagang yang
akan berdagang kepusat
kerajaan Majapahit, yaitu
melewati Pelabuhan
Surabaya, kemudian ke
Sungai Brantas dan terus ke
Majapahit. Lambat laun,
mereka itu membentuk
koloni-koloni untuk menetap
dan menyebarkankeyakinan-


keyakinan keberagamaannya.

Oleh karena itulah, wajah

Islam di Jawa merupakan

hasil dialog dan dialektika

antara Islam dan budaya

lokal yang kemudian menampilkan wajah Islam

yang khas Jawa (Muqoyyidin 2013)."

Berdasarkan

hasil

penelusuran sejarawan, karakteristik islam Indonesia mengacu pada islam sufistik Indo-persia dilihat dari kesamaan mazhab yang dianut antara masyarakat islam jawa dengan islam di wilayah Malabar dan Colomander. Kekhasan islam sufistik yang dapat berakulturasi dengan budaya local menjadikan agama islam mudah diterima oleh masyarakat Jawa (Muqoyyidin 2013: 25).

Berbagai kegiatan ritual menjadi kekhasan dalam masyarakat islam jawa seperti asyuro yaitu memperingati 1 Muharram, isra' mi'raj, mauludan dan sebagainya. (Muqoyyidin 2013: 26). Dengan demikian kegiatan memperingati hari besar agama islam dan kegiatan ritual secara rutin menjadi kearifan lokal masyarakat islam Jawa.

Guru yang ada di tiga sekolah memanfaatkan kegiatan keagamaan sebagai sarana untuk membuat orang tua murid terlibat dalam kegiatan sekolah. Tahlil dan istighosah rutin merupakan aktivitas rutin yang banyak dilaksanakan di daerah sidoarjo, surabaya maupun tuban, dengan memanfaatkan aktivitas keagaamaan yang menjadi kearifan lokal masyarakat di sekitar sekolah, sekolah dan guru telah berhasil menyedot perhatian orang tua untuk mau datang ke sekolah, berpartisipasi dalam kegiatan sekolah dan memungkinkan terjadinya komunikasi intensif antara guru, orang tua, dan murid, karena biasanya setelah dilaksanakan kegiatan keagamaan tersebut, akan ada sesi tanya jawab, sharing maupun caring.

b. Gotong Royong (Sambatan, Kerja Bakti, Sepi ing pamrih rame ing gawe, tepa selira)

Gotong royong merupakan warisan budaya Indonesia yang 
sudah diwariskan turun-temurun sejak jaman nenek moyang, gotong royong di setiap daerah memiliki berbagai macam nama dan istilah, di jawa ada istilah sambatan, grebuhan, di Kalimantan timur dikenal dengan paleo, di padang dikenal dengan hoyak tabuik, dan di sumatera utara dikenal dengan siada pari.

Adapun di daerah sekitar sekolah lokasi penelitian, gotong royong masih menjadi nilai kearifan lokal yang dipeliharan secara baik, walaupun untuk daerah surabaya yang notabene lebih kota dibanding sidoarjo atau tuban, semangat gotong royong dianggap sudah mulai menurun, namun semboyan dan katakata semangat gotong royong masih tetap dijaga, ada istilah sepi ing pamrih rame ing gawe yang ditunjukkan dengan berbagai aktivitas semisal di TK baiturrahman, terdapat aktivitas kerja bakti rutin, maupun kegiatan membangun sekolah secara gotong royong tanpa dibayar, ada semangat tepa selira, sebuah semangat untuk tenggang rasa yang ditunjukkan dengan berbagai macam cara oleh bebrapa sekolah, ada yang mengunjungi orang tua/siswa yang sakit, ada yang dalam bentuk membei sumbangan bagi teman yang sakit, menyumbang ke panti asuhan dan beberapa aktivitas lainnya.

c. Paguyuban wali murid;

Sejak zaman dahulu, masyarakat di daerah jawa sudah senang membuat paguyuban. Pada zaman sekarangpun banyak bertebaran paguyuban-paguyuban, semisal paguyuban sepeda onthel, paguyuban seni ludruk, paguyuban hadrah dan sebagainya. Nilai kearifan lokal tersebut dibaca sebagai sebuah peluang oleh guru yang ada di RA jannatul Abror Jl hamim Yasin Desa Plandirejo Plumpang Tuban. Masyarakat di sekitar sekolah tersebut banyak yang membuat paguyuban petani, peternak dan yang lain, akhirnya sekolah berinisiatif untuk membuat paguyuban wali murid, yang memiliki beragam aktivitas yang ditujukan untuk memfasilitasi wali murid bertemu, 
berkumpul, membuat acara dan sebagainya.

d. Ngalap Berkah (Ikhlas kiaine manfaat ilmune, patuh gurune barokah uripe)

Kearifan Lokal Ngalap

Berkah yang dimaksud adalah keyakinan yang dimiliki oleh masyarakat di sekitar tuban, sidoarjo maupun surabaya secara umum dan wali murid $\mathrm{TK} / \mathrm{Ra}$ di tiga sekolah tempat penelitian secara khusus bahwa Guru merupakan sosok yang wajib dihormati. Dengan menghormati guru, maka manusia akan memperoleh kebahagiaan baik berupa kebahagiaan dunia, kebermanfaatan ilmu maupun kebahagiaan akhirat. Beberapa ungkapan seperti Ikhlas kyaine manfaat ilmune (jika guru ikhlas, maka ilmu bermanfaat), atau patuh gurune barokah uripe (patuh guru membuat hidup penuh dengan berkah). Keyakinan seperti itu sebenarnya tidak ditanamkan oleh pihak sekolah, namun sudah melekat turun temurun dari zaman nenek moyang, dan diangap menjadi faktor yang bisa menguatkan keterlibatan orang tua dalam pendidikan, dengan adanya keyakinan tersebut, akan menyebabkan adanya komunikasi intens antara orang tua dan anak, dimana orang tua akan selalu memantau perkembangan anak agar perilakunya selalu hormat pada guru, orang tua juga akan memantau perkembangan anak melalui komunikasi dengan guru untuk melakukan kroscek dan komunikasi untuk menghormati guru sebegai sosok yang mbarokahi.

\section{SIMPULAN}

1. Kegiatan yang yang dikembangkan sekolah untuk mengembangkan keterlibatan orang tua di TK Falasifa surabaya, TK Baiturrahma Sidoarjo dan RA Jannatul Abror Tuban terdiri dari kegiatan umum dan kegiatan yang bernuansa kearifan lokal.

2. Adapun kegiatan umum yang dilakukan sekolah untuk mengembangkan keterlibatan orang tua dalam pembelajaran 
anak di sekolah dan di rumah terdiri dari parenting, komunikasi dengan orang tua, volunteer, danorang tua orangtua berperan sebagai guru dengan mengajarkan dan membantu anak untuk belajar di rumah

3. Adapun kegiatan bernuansa kearifan lokal yang dilaukan sekolah untuk mengembangkan keterlibatan orang tua dalam pembelajaran anak di sekolah dan di rumah terdiri dari (a) Kegiatan Keagamaan (Tahlil, istighosah, maulid, isra' mi'raj); (b). Gotong Royong (Sambatan, Kerja Bakti, Sepi ing pamrih, rame ing gawe, tepa selira) (c). Paguyuban wali murid; dan (d)Ngalap Berkah (Ikhlas kiaine manfaat ilmune, patuh gurune barokah uripe).

\section{DAFTAR PUSTAKA}

Ahmad, H. A.(2010). Kearifan Lokal sebagai Landasan Pembangunan Bangsa. Harmoni Jurnal Multikultural \& Multireligius. 34(IX). Hlm. 5-8.

Affandy, Didied dan Putu Wulandari. (2012). "An Exploration Local Wisdom Priority in Public Budgeting Process ol
Local Government".Int. J. Eco. Res. 5(III).:Hlm. 61-76.

Alfian, M. (2013)." Potensi Kearifan Lokal dalam Pembentukan Jati Diri Karakter Bangsa" Prosiding, Seminar Nasional Fisika dan PendidikanFisika Surakarta FKIP UNS. Prosiding The 5th International Cofereence on Indonesian Studies: "Ethnicity and Globalization". Jakarta: FIPB UI.

Asriati, Nuraini. (2012). "Mengembangkan Karakter Peserta Didik Berbasis Kearifan Lokal Melalui Pembelajaran di Sekolah". Jurnal Pendidikan Sosiologi dan Humaniora. 2 (III).

Beaty,J.J.(1984).Skills for Preschool Teachers. Columbus: Charles E. Merrill Publishing Company,

Coleman, M. (2013). Empowering Family-Teacher Partnership Building Connections within Diverse Communities. Los Angeles: Sage Publication.

Dryden \& J Voss. (1999). Learning Revolution. Torrance CA: The Learning Webb.

Erlendsdóttir,G." Effects of Parental Involvement in Education A Case Study in Namibia". 2010.M.Ed. Thesis Faculty of Education Studies, School of Education, University of Iceland. Diakses darihttp://skemman.is/stream /get/1946/6925/18121/1/ME d thesisGu\%C3\%B0laug.pdf (diakses pada 9 Desember 
2016).

Essa,E.L.(2014).Introduction to Early Childhood Education. Singapore: Cengange.

Fajarini, Ulfah. Peranan Kearifan Lokal dalam Pendidikan Karakter. Dalam Jurnal Sosio Didaktika: Vol. 1, No. 2 Des 2014.

Gunarsa,

D.(2003).PsikologiPerkemba ngan.Jakarta:

BPKGunungMulia.

Hamalik, O. (1990). Metode Belajar dan Kesulitan-kesulitan Belajar, Bandung: Tarsito

journals.com/index.php/tawarikh/arti cle/view/555.(diakses pada 10 oktober 2016)

Hornby. Parental Involvement in Childhood Education: Building Effective SchoolFamily Partnership. New York: Springer Science Business Media. 2011.

Ife, Jim. 2002. Community Development: CommunityBased Alternatives in an Aged Globalisation. 3rd ed. Australia: Pearson Education Australia.

Kamsari. 2015. "Mengenal Kebudayaan Masyarakat Pesisir Utara Jawa Timur Dan Madura." Pusat Kajian Sumber Daya Pesisir Dan Lautan Institut Pertanian Bogor. diambil dari http://pkspl.ipb.ac.id/beritamengenal-kebudayaanmasyarakat-pesisir-utarajawa-timur-dan-madura.html. (diakses pada 11 oktober 2016)
Komariah, Satori Djam'an and Aan. 2009. Metodologi Penelitian Kualitatif. Bandung: Alfabeta.

Magdalia, A. 2013. "Keroncong Music Re B Lects the Identity of Indonesia." Tawarikh: International Journal for Historical Studies 4 (2): 17186. Retreived from http://www.mindamas-

Mansur. 2005. Pendidikan Anak Usia Dini Dalam Islam. Yogyakarta: Pustaka Belajar.

Matthew B. Miles, A. M. Huberman. 1994. Qualitative Data Analysis. Arizona: Sage Publication.

Muqoyyidin, Andik Wahyun. "Dialektika Islam Dan Budaya Lokal Dalam Bidang Sosial Sebagai Salah Satu Wajah Islam Jawa." $E l$ Harakah 11 (1): 1-18. http://222.124.162.99/index.p hp/ibda/article/download/64/3 8. 2013.

Nurahayati, Dani. 2011. Motivasi Dan Prestasi Belajar Siswa Dalam Pembelajaran Matematika Ditinjau Dari Kelakatan Anak-Orang Tua. Yogyakarta.

http://eprints.uny.ac.id/7363/.

Patmonodewo, Soemiarti. 2003. Pen didikanAnakPrasekolah. Jakarta: RinekaCipta

Patrikakou, Evanthia N. The Power Of Parent Involvement: Evidence, Ideas, And Tools For Student Success. United States: Academic Development Institute, 2008. Print. 
Pelibatan Orang Tua Bernuansa..... Wahyuniati, Husni Abdillah

Rahyono, F.X. 2009. Kearifan Budaya Dalam Kata. Jakarta: Wedatama Widyasastra.

Redaksi. "Sekdaprov Jatim: Masyarakat Pesisir Utara Jatim Miliki Karakteristik Budaya Yang Khas Beritalima." Beritalima.

SlametSuyanto. 2005. Pembelajaran untuk Anak TK. Jakarta: Depdiknas.

Sugiyono. 2013. Metode Penelitian Kualitatif Dan $R \& D$. Bandung: Alfabeta.

Sukmadinata, N. S. (2010). MetodePenelitianPendidikan. Bandung: RemajaRosdakarya.

Taylor, Steven, Robert Bogdan, and Majorie DeVault. 2016.
Introduction to Qualitative

Research Methods: A

Guidebook and Resource. Wiley.

Wahy, Hasbi. 2012. "Keluarga Sebagai Basis Pendidikan Pertama Dan Utama." Didaktika XII (2): 245-58.

Zuchdi, Darmiyati. 2010. "Pengembangan Model Pendidikan Karakter Terintegrasi Dalam Pembelajaran Bidang Studi Di Sekolah Dasar." Cakrawala Pendidikan 29 (1): 1-12. http://journal.uny.ac.id/index. $\mathrm{php} / \mathrm{cp} / \mathrm{article} / \mathrm{download} / 224 /$ 143. 